\title{
HISTOLOGICAL AND MICROBIOLOGICAL ASPECTS OF ACTINOMYCETOMA CASES IN VENEZUELA
}

\section{S U M M A R Y}

\begin{abstract}
A ten year (1976-1986) review study of cases of Actinomycetoma in Venezuela was made through personal interview and clinical examinations, analysis of medical records of patients with actinomycetoma, histological studies of biopsy samples, as well as microbiological studies of isolates strain, also through out personal interviews with researchers and dermatologists who were sources of information on mycetoma cases. A total of 47 cases were recorded.

As etiologic agent Actinomadura madurae was found in 20 cases $-(42.5 \%)$, Nocardia brasiliensis in 13 cases $(27.6 \%)$, Nocardia spp 7 cases $(14.8 \%)$, Streptomyces somaliensis in 4 cases $(8.5 \%)$, N. asteroides in 2 cases $(4.2 \%)$ and $\mathbf{N}$. otitidis caviarum, ( $N$. caviae) in 1 case $(2.1 \%)$. Most of the reported cases involved individuals living and working in rural areas, mostly males who outnumber females $4: 1$. The patients were 18 to 80 years old. A. madurae was reported as the most frequent etiologic agent. Most of the clinical cases were seen when the disease was well established. Twenty four of the forty seven cases reported were observed in Lara State, which represents a $51.0 \%$ of all the cases studied
\end{abstract}

KEY WORDS: Actinomycetoma - histopathology - incidence in Venezuela; Aero bic actinomycetales.

The term "Mycetoma" was used for the first time in 1860 by van Dyke Carter, to denote a fungus tumoral disease of the foot, later named "Madura foot" due to its prevalence in the province of Madura, India. 1 Mycetoma are caused by fungi (Eumycetoma) or by aerobic actinomycetales (Actinomycetoma). In order of frequency, the etiologic agents of the actinomycetoma are:
Actinomadura madurae, Nocardia brasiliensis, Streptomyces somaliensis, N. asteroides, N. otitidis caviarum, (N. caviae), A. pelletieri, S. paraguayensis and Nocardia dassonville $i^{2,}{ }^{8,50}$.

Actinomycetoma usually begins at the site of a minor localized injury, most frequently induced by a thorn or a splinter soil contaminated.

\footnotetext{
This work was presented at the 2nd International Symposium on Mycetomas. Taxco, México, (16 to 20 october, 1987 ).

(1) Department of Pathology, School of Medicine University of Los Andes, Merida 5101 . Venezuela.

(2) Department of Medical Microbiology, School of Medicine, University of California. Davis, CA 95616, USA

(3) Dermatology Service, Central Hospital "Antonio M. Pineda" and School Medicine "Universidad Centro Occidental Lisandro Alvarado" UCLA. Barquisimeto, Venezuela.

(4) Pathology Service. IVSS "Pastor Oropeza" Hospital, Barquisimeto, Venezuela

(5) Microbiology Department UCLA, Barquisimeto, Venezuela.
} 
SERRANO, J. A.: BEAMAN, B.; MEJIA, M. A.; VILORIA. J. F. \& ZAMORA, R. - Histological and microbiological aspects of actinomycetoma cases in Venezuela. Rev. Inst. Med. trop. São Paulo, 30 (4): 297-304, 1988.

As a consequence, the disease is more commonly localized on the feet. The traumatic inoculation of the organisms into the skin often causes primary cutaneous or subcutaneous infections, which clinically are recognized as the "Mycetoma Syndrome". The characterists of this syndrome are the presence of oedema, sinus tracts and granules $^{8,9,22,32,38,54 .}$

Minimycetomas, as well as chancriform le sions involvement of the regional lymph nodes, with a clinical picture similar to sporotrichosis ${ }^{3}$. 6. $18,23,29,30,34,35,43.48$ has been reported in the infection by $\mathbf{N}$. brasiliensis.

In Venezuela, Actinomycetoma is the most frequently recognized form of disease caused by the aerobic actinomycetes ${ }^{3 .}$ 5. 12. 17. 19. 21. 24, 33. 36. 41. 44, 47, 51,55,56,58,59. There is a noticeable lack of epidemiological studies to ascertain the incidence of diseases caused by these microorganisms. CAMPINS ${ }^{13} .{ }^{17}$, CONVIT et al ${ }^{19}, \mathrm{AL}$ BORNOZ. ${ }^{5}$ and SERRANO et al ${ }^{51}$ have reported isolated cases of Actinomycetoma infections through different Venezuelan areas.

The present paper is a review of cases of Actinomycetoma in Venezuela during a ten year period (1976-1986). All cases were reviewed and study in his clinical, histological and microbiological aspects.

\section{MATERIAL AND METHODS}

The data related to the present paper were obtained as follows: 1) Personal interview and clinical examinations of patients. 2) Analysis of medical records of mycetoma patients. 3) Personal interviews with Dra. María Cecilia de Albornoz from the Biomedicine Institute, Caracas: Dr. Dante Borelli and Dra. Carmen Marcano from the Institute of Tropical Medicine "Universidad Central de Venezuela", Caracas; Dr. Gregorio Volcan, "Universidad de Oriente" School of Medicine, Ciudad Bolivar State, Dr. Hernán Vargas, Dra. Nieves Vargas de Caminos and Lic. Luz Mila Meza, School of Medicine, "Universidad del Zu lia" Maracaibo, Venezuela. Lic. Cristina Pérez "Universidad de Carabobo" La Morita, Maracay, Aragua State; Dr. E. Sawertein "Hospital Gene ral Luiz Razetti" Barinas, Barinas State and Lic. Francisco Yegres "Universidad Experimental
Francisco Miranda", Coro, Falcón State. All of the above mentioned persons provided information on cases that they had observed as well as on sources of biopsy samples and of some of the microbiologically studied strains.

The diagnosis of actinomycetoma of the cases studied, were based on: a) Clinical and epide miological features. b) Histological examinations (H \& E) stain of biopsy samples. c) Microbiological examination of 30 cultures that were isolated from mycetoma patients. The microbiolo gical studies were performed according the following methodology. 1) Morphological studies of the culture growth in Brain Heart Infusion (BHI). The Gram and Kinyou methods were used as staining procedures. The physiological and biochemical properties, such as decomposition and proteolytic activities, utilization of nitrogenous compounds, sensitivity to Lysozyme and utiliza tion of sugars, were studied as recomended by GOODFELLOW et $\mathrm{al}^{25.26}$ GORDON \& $\mathrm{MIHM}^{27}$ ${ }^{28}$ and BERD ${ }^{10}$.

The whole cell chemotype, as well as the li pids, were evaluated according MORDARSKA et $\mathrm{al}^{37}$ and LECHEVALIER \& LECHEVA LIER $R^{39 \cdot 40}$. The final diagnosis and classification of the study strain was based on GOODFE LLOW \& CROSS $^{24}$.

\section{RESULTS}

In Venezuela, Actinomycetoma has been the most frequently recognized form of disease caused by the organisms that produce Mycetoma (See Table 1). All the cases studied were the re sults of observations and diagnosis made during a 10 year period (1976-1986). A total of 47 cases were recorded. Table 2 shows the distribution by States of Venezuela of the studied cases and its etiological agents. Out of the 47 cases (see Table 3 ) twenty cases were caused by A. madurae (12 cases were microbiologically confirmed and 8 by histological diagnosis). N. brasiliensis, was reported in 13 cases, all microbiolo gically confirmed. Nocardia spp. was observed in 7 cases (diagnosis based on "small granule", $H$ \& E observations) $S$. somaliensis, 4 cases (2 cases were microbiologically confirmed and $2 \mathrm{ca}$ ses through histology). N. asteroides in 2 cases microbiologically confirmed and $\mathbf{N}$. otitidis ca- 
SERRANO, J. A.: BEAMAN, B.; MEJIA, M. A.; VILORIA, J. E. \& ZAMORA, R. - Histological and microbiological aspects of actinomycetoma cases in Venezuela. Rev. Inst. Med. trop. São Paulo, 30 (4): 297-304, 1988

viarum in 1 case. In Table 4 are shown the results of the physiological, biochemical and chemota xonomyc studies of thirty of the culture proven cases of Actinomycetoma.

TABLE 1

Reported cases of actinomycetoma in Venezuela, until 1986

\begin{tabular}{|c|c|c|c|c|c|c|c|}
\hline \multirow[t]{2}{*}{ Author(s) } & \multirow[t]{2}{*}{ Reference } & \multirow[t]{2}{*}{ Year } & \multirow[t]{2}{*}{ state } & \multirow{2}{*}{$\begin{array}{l}\text { Number of } \\
\text { cases }\end{array}$} & \multirow[t]{2}{*}{ Etiologic Agent } & \multicolumn{2}{|c|}{ Diagnosis by } \\
\hline & & & & & & Histology & Culture \\
\hline Rangel & 45.46 & 1909 & $\begin{array}{l}\text { Federal } \\
\text { Distrit. }\end{array}$ & 1 & A. madurae & + & $-\infty$ \\
\hline Cuenca & 20,21 & 1927 & Zulia & 1 & $N$. brasiliensis & + & + \\
\hline Briceno \& Villalobos & 12 & 1927 & Lara & 1 & $\mathbf{N}$. brasiliensis & + & + \\
\hline O'Daly & 44 & 1938 & Aragua & 1 & A. madurae & + & + \\
\hline Montemayor & 36 & 1950 & $-\cdots$ & 1 & N. asteroides & + & + \\
\hline Velutini & 56 & 1951 & Lara & 1 & N. asteroides & + & + \\
\hline Salas \& Borelli & 47 & 1955 & -- & 1 & N. brasiliensis & + & + \\
\hline \multirow[t]{3}{*}{ Campins } & 13.15 & 1955 & Lara and Yaracuy & 4 & N. brasiliensis & + & + \\
\hline & & & & 3 & A. madurae & + & + \\
\hline & & & & 4 & unknow & + & - \\
\hline Alarcon et al. & 3 & 1956 & Miranda & 1 & N. brasiliensis & + & + \\
\hline Barnola et al. & 7 & 1956 & Lara & 1 & $N$. brasiliensis & + & + \\
\hline Montemayor & 33 & 1958 & -- & 1 & N. brasiliensis & + & + \\
\hline Rincón, F, G et al. & 44 & 1961 & Zulia & 1 & S. pelletieri & + & + \\
\hline \multirow[t]{2}{*}{$\begin{array}{l}\text { Convit et al } \\
\text { (review cases) }\end{array}$} & 19 & 1961 & $\begin{array}{c}\text { Lara } \\
\text { Zulia } \\
\text { Miranda } \\
\text { Federal }\end{array}$ & 9 & N. brasiliensis & + & + \\
\hline & & & Distrit. & 7 & A. madurae & + & + \\
\hline Borelli, \& Leal & 11 & 1969 & $\begin{array}{l}\text { Andean } \\
\text { región }\end{array}$ & 1 & N. brasiliensis & + & + \\
\hline Vargas & 55 & 1973 & Zulia & 1 & S. somaliensis & + & + \\
\hline Zamora et al. & 59 & 1974 & Lara & 1 & N. brasiliensis & + & + \\
\hline Albornoz et al. & 4 & 1977 & Miranda & 1 & A. madurae & + & + \\
\hline Volcan & 58 & 1978 & Bolivar & 1 & N. brasiliensis & + & + \\
\hline \multirow[t]{7}{*}{$\begin{array}{l}\text { Albornoz } \\
\text { (review cases }\end{array}$} & 5 & 1978 & $\begin{array}{c}\text { Anzoátegui } \\
\text { Aragua }\end{array}$ & 1 & Nocardia spp & + & + \\
\hline & & & Falcón, Guárico & 19 & N. brasiliensis & + & + \\
\hline & & & Lara, Miranda & 9 & A. madurae & + & + \\
\hline & & & Sucre. Zulia & 3 & N. asteroides & + & + \\
\hline & & & & 3 & S. somaliensis & + & + \\
\hline & & & & 1 & A. pelletieri & + & + \\
\hline & & & & 2 & Nocardia $s p p$ & + & + \\
\hline \multirow[t]{6}{*}{ Serrano et al } & 51 & 1985 & Lara \& Falcón & 10 & A. madurae & $+(8)^{* * * *}$ & $+(2)^{k: k * k}$ \\
\hline & & & & 5 & $\mathrm{~N}$, brasiliensis & + & + \\
\hline & & & & 2 & N. asteroides & + & + \\
\hline & & & & 1 & N. caviae (otitidis caviarum) & + & + \\
\hline & & & & 13 & Nocardia spp & + & - \\
\hline & & & & 4 & S. somaliensis & $+(2)^{: k: k *}$ & $-(2)^{k * * k}$ \\
\hline
\end{tabular}

* means: diagnosis made by microscopic observation of the grain

*.k means: no culture obtained.

H: Cases.

The histological studies reveal that in the Actinomycetoma caused by Nocardiae, the $\mathbf{H} \&$ $E$ stain shows the presence of small deep blue oval or round grains. These grains have a peri feral zone composed mainly of filamentous cells, which often present a club shape and a central zone partially stained in blue or red colour where short type bacillar and coccoidal forms were observed. The tissue reaction pattern in these cases were that of a microabscess surrounded by granulation tissue. These kind of granules and tissue reaction pattern was observed in 23 of the stu 
SFRRANO. J. A.: BEAMAN, B: MEJIA, M. A: VILORIA. J. E. \& ZAMORA, R. - Histological and microbiological aspects of actinomycetoma cases in Venezuela. Rev. Inst. Med. trop. Säo Paulo. 30 (4): 297304.1988.

TABLE 2

THE DISTRIBUTION OF ACTINOMYCETOMA IN DIFFERENT STATES OF VENEZUELA (1976-1986)

\begin{tabular}{l|c|c|c|c|c|c|c|}
\hline \multicolumn{7}{|c|}{ ORGANISM } & \\
\hline ARAGUA & 2 & & & & & & 2 \\
BARINAS & & 1 & & & & & 1 \\
FAICON & 2 & 2 & & & 2 & & 6 \\
IED. DIST & 2 & 2 & & & 1 & & 5 \\
I ARA & 8 & 5 & 2 & 1 & 4 & 4 & 24 \\
MIRANDA & 3 & 2 & & & & & 5 \\
YARACUY & 1 & 1 & & & & & 2 \\
ZIILIA & 2 & & & & & & 2 \\
\hline TOIAL & 20 & 13 & 2 & 1 & 7 & 4 & 47 \\
\hline
\end{tabular}

TABLE 3

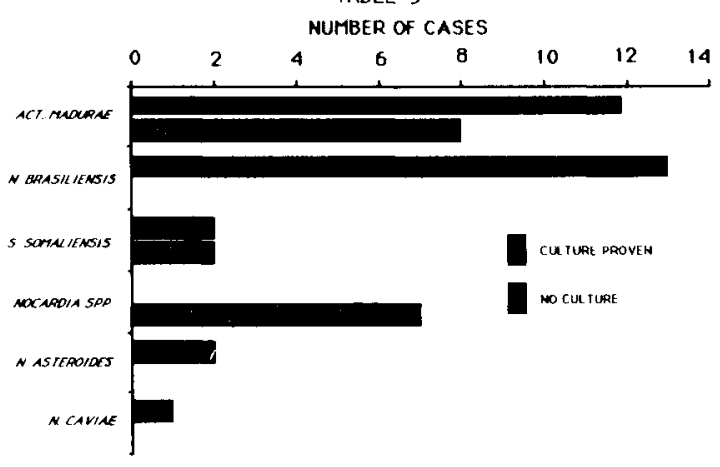

ACTINOMYCETOMA IN VENEZUELA (1976-1986)

TABLE 4

Physiological and chemotaxonomic characteristics of 30 strains, isolate from actinomycetoma cases in Venezuela

\begin{tabular}{|c|c|c|c|c|c|}
\hline TEST & $\begin{array}{l}\text { A. Madurae } \\
112 \text { strains) }\end{array}$ & $\begin{array}{l}\text { N. asteroides } \\
12 \text { strains }\end{array}$ & $\begin{array}{l}\text { N. brasiliensis } \\
113 \text { strains }\end{array}$ & $\begin{array}{c}\text { N. otitidis caviarum } \\
(1 \text { strain })\end{array}$ & $\begin{array}{l}\text { S. somaliensis } \\
(2 \text { strains })\end{array}$ \\
\hline Gram & + & + & + & + & + \\
\hline Acid fastness & -- & $\pm:$ & $\therefore$ & $\therefore$ & $\ldots$ \\
\hline \multicolumn{6}{|l|}{ Hydrolysis and } \\
\hline Casein & + & - & + & - & + \\
\hline Hypoxanthine & + & - & + & + & -- \\
\hline Starch & + & + & +3 & + & + \\
\hline Tyrosine & + & - & + & - & + \\
\hline Urea & $\ldots$ & + & + & + & - \\
\hline Xanthine & - & $\ldots$ & - & + & \\
\hline \multicolumn{6}{|l|}{ Acid. Production from } \\
\hline Cellobiose & + & - & $\ldots$ &.- & - . \\
\hline 1 inositol & +4 & - & + & + & - \\
\hline d mannitol & + & $\ldots$ & + & + & $\ldots$ \\
\hline Xylose & + & - & - & - & -. \\
\hline Resistance to Lysozyme & - & + & + & + & - \\
\hline Nitrite from nitrate & + & + & + & + & - \\
\hline \multicolumn{6}{|c|}{$\begin{array}{l}\text { Whole organism hydrolysate } \\
\text { analysis }\end{array}$} \\
\hline $\mathrm{DL}-\mathrm{DAP}$ & + & + & + & + & - \\
\hline $\mathrm{LL}-\mathrm{DAP}$ & - & $\sim \cdots$ & - & - & + \\
\hline Micolic Acid thin & - & + & + & + & - \\
\hline layer spot. & & & & & \\
\hline
\end{tabular}

1 Table shows most significative results

2 a weak reaction was observed

36 strains were negative

44 strains were negative

died cases. The histological observations of the A. madurae cases ( 20 cases) present a typically multilobed or vermin-shaped grain with a peripheral deep blue band and a colorless or faint blue center. The tissue reaction pattern is that of a non specific inflamatory reaction with $\mathrm{mi}$. croabscess formation surrounded by macrophages with a foamy cytoplasm, resulting in a lesion 
SERRANO, J. A.; BEAMAN, B.; MEJIA, M. A.; VILORIA. J. E. \& ZAMORA. R. - Histological and microbiological aspects of actinomycetoma cases in Venezuela. Rev. Inst. Med. trop. Sáo Paulo, 30 (4): 297304.1988.

that has the appearence of an "histiocytic granu loma".

The lesions produced by $\mathbf{S}$. somaliensis 4 cases) show a typical granulomatous tissue reac tion, composed of epithelioid and giant cells that surrounded the parasitic grain. Fibrosis is obser ved around the periphery of the lesions. The gra nules are round or oval compact. They are com posed of a matrix of amorphous material sho wing some artificially produced slits. The matrix may show some affinity for eosin at the periphery but no clubs shapes were observed. In the pre sent report A. madurae was found to be the most frequent agent of mycetoma (20 cases), followed by $\mathbf{N}$. brasiliensis (13 cases). The majority of the studied patients were 30 to 59 years old. As reported in previous studies, we observed that the most frequent location of the mycetoma was on the foot ( 30 cases), followed by the leg (6 cases). Most of the patients $(80 \%)$ were peasants and men were more commonly affected (35 cases. $74.5 \%$ ) than women ( 12 cases, $25.5 \%$ ).

\section{DISCUSSION}

There have been no detailed studies attemp ting to determine the extent or epidemiology of Actinomycetoma throughout Venezuela. The present paper is based on cases reported in the literature and on personal communications with dermatologists at some of the key hospitals, 121 cases). The data for the remaining 26 cases were obtained by personal interview with the patients. Currently it is not possible to state preva lence of the disease in Venezuela. In the Vene zuelan literature on mycetoma one can find about 96 actinomycetoma cases reported in the whole country (Table 1). By studying histologic sections of biopsy samples from 30 culture pro. ven cases, as other investigators have previously reported ${ }^{22.38 .51 .57}$, we were able to identify causal agent with a $100 \%$ correlation with the microbiological results.

The importance of histological examination of actinomycetomas, as shown in the present study, is evident by the fact that the causal agent of the actinomycetoma could be recognized in 40 of 47 cases by histology alone. There is no doubt that histological diagnosis has limitations since in the present report 7 cases could be diag nosed only as Nocardia spp since no culture was possible. However the clinical, and radiological examination and the response to the treatment confirmed the presumptive diagnosis. In these studies the histological diagnosis was based upon the size and shape of the granules as well as in the characteristic of the cellular and tissue reaction pattern. It is important to emphasize that the histological examination should be sup plemented by simultaneous culture either of biopsy tissues or granules when obtained.

In Venezuela actinomycetomas are obser ved more commonly than eumycetomas ${ }^{5}$. 15. 1s. 51. 52. According to current reports A. madurac is the most frequent etiologic agent of actinomy. cetoma in Venezuela. Similar results have been reported in India by PANK AJALAKSHMI et al ${ }^{4: 2}$ and in the United States by TIGHT et al ${ }^{53}$ LA. $\mathrm{CAZ}^{31}$, and LAVALLE ${ }^{32}$ indicated that N. brasiliensis is the most common etiologic agent of actinomycetoma in Brazil and México respec. tively. Most of the reported cases involve indivi duals living and working in the rural areas and the majority of these infections are in males. which outnumber females by a $4: 1$ ratio. The patients ages ranged from 18 to 80 years, and their occupation is usually either field laborers, herds men or peasants. Only 3 cases of Actinomyce toma were diagnosed in persons residing and working within urban areas: two of these were caused by $\mathbf{A}$. madurae and 1 case caused by $\mathbf{N}$. brasiliensis. Most of the clinical cases were observed after the disease was well established within the host, and the individuals sought medical attention only after the disease had progres sed to the stage of being debilitating. Venezuela has many rural communities and some of them are far away from the large metropolitan hospitals. Most of the inhabitants of these rural areas have a low income and belong to lower socioeco nomic group. Because of these factors it is diffi cult to make an early diagnosis of infections cau sed by these actinomycetes, thus resulting in a potentially serious problem. Actinomycete in fections that are recognized early frequently res pond to therapy, whereas those infections that have been allowed to progress are not prone to successful treatment. It is interesting to note that according to CONTI-DIAZ ${ }^{18}$ mycetomas in Uruguay are usually diagnosed early. This is due to prompt medical consultation, the absence of 
SERKANO J A BEAMAN B MFJA. M A VILORIA J F \& ZAMORA. R - Histological and microbiological

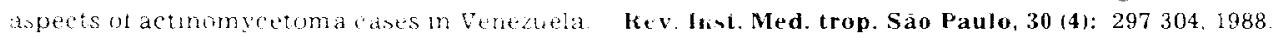

signucant geographical obstacles and the exis tence of an adequate healu education program In other countries, such as venezuela, Brazil. In dia. Mexico or Sudan S2 $^{2}+2: 1 \%$. the existence of numerous geographical barriers. vast territo rits and madequate health educaton of the po pulation discourage patlents with this not jainful distase from seeking prompt medical advice.

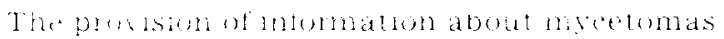
10 physuldrs medical studerts, nurses ard pa ranedicals working in countres where myceto mas are endemic is also important.

\section{RESUNO}

Aspectos histologrcos e microbiologicos de casos de actinomicetoma na Venezuela.

Os autores, em um periodu de 10 anos (1976 1986) realizal am um estudo clinico histo patologicue micologico em 47 casos de actinomicetoma Os agentes etiologicos isolados foram: Actinomadura madurae -20 cases $142.5 \%$ : Nocatdia brasiliensis - $13 \cos 0 \mathrm{~s}(27.6 \%$ : Nocardia spp - 7 casos $(14,8 \%)$, Streptomyces somaliensis -4 casos $(8.5 \%)$. Nocardia asteroides - 2 casos $(4,2 \%)$ e $\mathbf{N}$, otitidis caviarum ( $\mathbf{N}$. caviae) -1 caso $(2.1 \% 1$. A maioria dos casos procedia de zona rural. prevalecendo a infecça no sexomascu lino $14: 1)$. A idade dos pacientes variou de 18 a 80 anos. Dos 47 casos registrados, 24 foram observados no Estado de Lara. representando 51\% do total das observacoes.

\section{ACKNOWLEDGEMENTS}

This investigation was supported by Grants from the "Consejo Nacional de Investigaciones Cienuficas y Tecnologicas" (CONICIT) Caracas, Venezuela, N: S1-1263. "Consejo de Desarrollo Cientifico y Tecnológico (CDCHT) from the University of Los Andes, Mérida, Venezuela. N" M 154-79 and by the "Ministerio de Sanidad y Asistencia Social (SAS) Venezuela".

We thank Yolanda Bartolome and Enrique Garcia for their technical help, Rosario Quintero for typing the manuscript. Rafael Simón Oro peza for his assistance as a driver in the field work As well as the staff from the "Unidad de Investigaciones en Ultraestructura" CADISUCLA Barquisimeto, Venezuela 'This research has been conducted as part of a cooperative effort of the International Group for the study of the pathogenicity of the Actinomycetes (IGSPA).

\section{REFERENCES}

1. ABBOT, P. Mycetoma in the Sudan Trans. roy. Soc. Irup. Hed. Hyg., 50: 1131,1956

2 AJELLO. L \& BROWN J - Actinomycetoma caused by Nocardiopsis dassonvillei. Arch. Derm., 123 426. 1987.

3. ALARCON C. J OBADIA. J \& BORELLI. D - Nocardia brasiliensis aislada de un caso de linfangitis nodular aguda supurativa. Dermatologia, 1:269285, 1958

4. ALBORNOZ, M. B. de; RODRIGUEZ, G. G. \& URDA NETA. G. D. .- Micetomas de localization podal de etio Jogra doble Sabouraudia, 15: 187 193. 1977

5. ALBORNOZ, M. B. de - Micetomás en Venezuela. In SIMPOSIO INTERNACIONAL DE MICETOMAS. Bar quisimeto, Venezuela, 1978. Proceedings. Barquisimeto. Centro Tecnologia Educativa. 1978 v. 1. p. 170177.

6. ARENAS, R.: LAVALLE, P PENALOZA. A \& AQUINO M. A. --- Minmycetomas multiples dus a Nocardia brasiliensis, presentation de deux cas Bull. Soc. franc. Mycol. Med.: 10: 7376,1981 .

7. BARNOLA, J. \& VELUTINI. L. - Micetoma podal por Nocardia brasiliensis. Rev. lat. amer. Anat. pat., 2: 5158. 1958

8. BEAMAN, B. L. - Actinomycete pathogenesis. In: GOOD FELLOW, M.: MORDARSKI, M \& WILLIAMS, S. T.. ed - The biology of the actinomycetes. London. Academic Press. 1984 . p. 457479.

9. BEAMAN, B. L. .-. Possible mechanisms of Nocardial pa thogenesis. In: GOODFELLOW. M: BROWNELL. G. H. \& SERRANO.J.A., ed. -- The biology of the nocardia. London. Academic Press, 1976. p. 386417

10. BERD, D. - Identification of 'linically mportant aerobic actinomycetes. Appl. Microbiol., 25. 665681.1973

11. BORELLI, D. \& LEAL, J. - Mycetoma successfully trea ted with ethambutol. Trans. roy. Soc. trop. Med. Hyg, 63 881882,1969

12. BRICEÑO IRAGORRY, L. \& VILLALOBOS, T. - Un caso de pie de madura. Bol. Hosp. (Caracas), 18: 457, 1927.

13. CAMPINS. H. - Epidemiological aspects of deep mycosis in Venezuela. Mycopathologia (Deen Haag), 13: $25 \cdot 32$. 1960 .

14. CAMPINS, H: BARNOLA, J. \& BRICENO MASS, T. Labor realizada en el campo micológico. Mycopathologia (Deen Haag), 15: 53-60. 1961. 
SFRRANO, J A BFAMAN B: MFJIA. M A: VILORTA J E \& ZAMORA. R. - Histological and microbiologleal

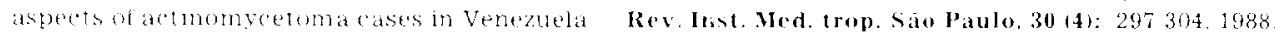

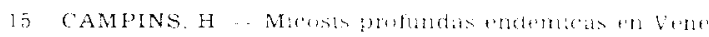
?U2la. In CONGRESG VENEZOLANO CIENCIAS MEDICAS, 6. Caracas. Venezuela, 1957 Proceedings. Ca-

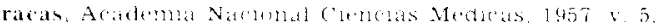
1.) 27872876

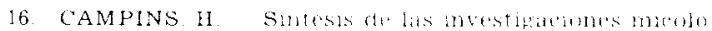
gicas tedizadas en Venemula durante los anos 29461956

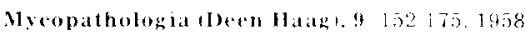

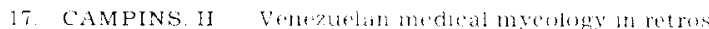
peet In INTERNATIONAL CONFERENCE ON THE MYCOSES. 5. Caracas, 1980 . Proceedings. Washington. PAHO . 1980 1. 611 iscient. Publ N. 396

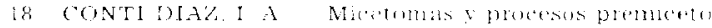

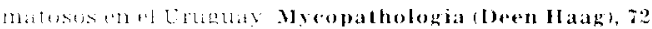
5464,1980

19 (ONVIT I BORELLI I) ALBORNOZ R RODRI GLES. C \&OMEZ CH J Micetomas cromomicosis. esporotricosis y enfermedad de Jorge Lobo. Mrcopatho-

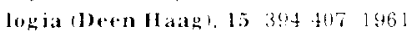

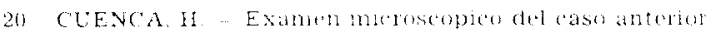
In EMPAIRE A D Su obra escrita Cararas Talleges Hpouratices de las Laburaturies Bingen, 1941

21 CUENCA.H . Nota sobre un caso de micetoma a granos blances de vinent Rev soc med-quir. Zulia, 156157. 1927

22. DESTOMBES F CAMAIN $R$ \&AZIMOFF, $O$.-. Anà tomic patholoreque des Mreetomes et dupled de Madura (n particulier Bull. Soc, Path. exot.,51: $863875,1958$.

23 GEZUELE.E. CONTI IIAZ. I A. BLRGOA. F. \& JIME NEZ. C. H. de .... Anute Wmohangrte Nocardiests. Brit. J. Derm., 89:305 307, 197\%

24. GOODFELLOW. M \& CROSS. T. Classitiation. In GOODFELLOW. M. MORDARSKI. M. \& WILLIAMS. S T. ed The biology of the actiongectes. Londor. Ara demic Press. 1984 p 7164

25. GOODFELLOW. M. \& SCHALL, K. F. Identification methods for Nocardia. Actinomadura and Rhodococeus In: LOVELOCK. D. W \& SKINNER, F A ed - Identification methods for microbiologists. London. Acadromice Press. 1979. p. 261276

26

GOODFELLOW, M : ALDERSON G \& LACEY J.. N merical taxonomy of Actmomadura and related actino mycotes J. gen. Microbiol.. 111:95111.1979.

GORDON, R E \& MIHM. I M. Identifieation of Nocardia caviae Erikson now comb. Ann. N. Y. Acad Sci. 98: $628 \cdot 636,1962$

GORDON. R. E. \& MIHM. J. M. A comparativestudy of some strain levered as nocardial J. Bact.. $33 \quad 1527.1957$

29. GUY.W H. Nocardiosis cutis resembling sporotricosis. Arch. Derm. Syph. (Chic.1.2 137, 1920

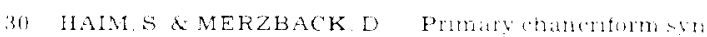
drome caused by Nocardia asteroides. Mykosen. 22 $360) 363 \quad 1976$

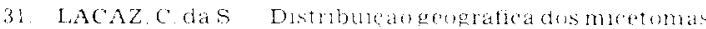
no Brasil An bras. Derm. of i67 172 t 981

32. LAVALLE P MUrimas in Mexien In SIMPOSIO INTERNACIONAL DE MICETOMAS Barquisimeto, Ve nefuela i 978 . Proceedings, Barquisimeto Centro Tecno logra Educativa 1978 v. : p 755150

33. MACKINNON J. E. ARTAGAVEYTIA ALLENDE R C \& ZORRAN, N . The mbibury "ffect of chemothere weute agents on the growe of the palusal organisms of

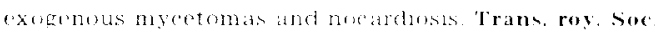
trop. Ned. Hyk. 5?: 7886 : 145

34 MACKINNON I E CUNTIMAZ I A GEZLELE E

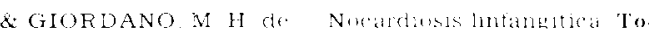
$\mathrm{rax}, 17.7883 \quad 1968$

35. MITCHELL. G: WELLS, G M \& GOODMAN, J $S$.. Sporotrichoid Nocardia brasiliensis anfectom Amer. Rev resp. 1)is., 112: 721723,1975

36. MONTEMAYOR. L. - Sintesis estadistea y algunascon

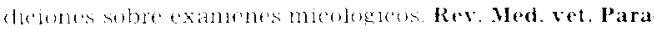
-it. Maracay, 985. 1950

37. MORDARSKA.J. MORDARSKI.M \& GOODHELLOW M. Chemotaxomomic characters and classification of so me notardioform bacteria. J. gen. Microbiol., $83 \quad 1527$ 1972

38. NOVALES.J.- Diagnostico histologicodelos micetomas segun los granos. In: SIMPOSIO INTERNACIONAL DE MICETOMAS. Barquisimeto, Venezucla 1978. Proceedings. Barquisimeto, Centro Tecnologia Educativa, 1978 v. 1. p. 5259

39. LECHEVALIER. M. P. \& LECHEVALIER, H A Ch mical composition as a criterion in the classification of aerobic actinomycetes. Int. J. system. Bact., 20435443. 1970 .

40. LECHEVALIER, M. P. \& LECHEVALIER, H. A. Com position of whole cell hydrolysates as a criterion in the classification of acrobic actinomycetes. In: PRAUSER. H.. ed. ... The Actinomycetales. Jena. Gustav Fischer Ver lag. 1970 , p. 311316

41. ODALY. J. A Alromas sobre micosis en Veneruela Micetoma de la mano por Actinomyees madurae. Rev. Policlin. Caracas, 38: 2785 2792. 1938

42. PANKAJALAKSHMI, V. V. \& TARALAKSHMI. V. V. -Mycetomas in the tropic Indian J. Path. Mictobiol., 27 223228.1984

43 RAPAPORT J - Primary chancrifom syndrome caused by Nocardia brasiliensis. Areh. Derm., 93:62 64.1966

44 RINCON F G HOMEZ CH J CASAS. G \& WENG NER. F -. Micetoma dr granos rolos por streptomyces pelletieri. Primer caso venezolano. Rev. Soc. med.quir. Zulia, 35 número especiall: 1136.1961 
SERRANO. J. A: BEAMAN. B.; MEJIA. M. A.: VILORIA. J. E. \& ZAMORA, R. - Histological and microbiological aspects of actinomycetoma cases in Venezuela. Rev. Inst. Med. trop. Sào Paulo, 30 (4): 297304.1988

RISQUEZ. J. R. A... A proposito de pie de Madura. Bol Hosp. (Caracas), 18: 454.457, 1927

RISQUEZ.J.R - Estado actual de la parasitologia en Venezucla Caracas. Tip. Americana, 1910. (Tesis -- Uni versictad Central de Venezuela. N" 901.

47. SALAS A \& BORELLI, D. - Micetoma torácico produ. cido por Nocardia brasiliensis. In: CONGRESO VENE ZOLANO CIENCIAS MEDICAS, 6. Caracas, Venezucla, 1957. Proceedings. Caracas. Academia Nacional de Cien clas Médicas, 1957. v. 5, p. 2903291

48. SATTERWHITE, T. K. \& WALLACE, R. J. - Primary cutaneous nocardiosis, J. Amer. med. Ass., 242: $333-336$. 1979

49. SCHAAL K. P. - Laboratory diagnosis of actinomycete diseases. In: GOODFELLOW. M.: MORDARSKI, M \& WILLIAMS, S. T., ed. -- The biology of the actinomycetes. London, Academic Press, 1984.p. 425-456

50. SCHAAL, K. P. \& BEAMAN, B. L. - Clinical significance of the Actinomycetes. In: GOODFELLOW. M.: MOR DARSKI. M. \& WILLIAMS. S. T.. ed. - The biology of the actinomycetes. London. Academic Press. 1984. p 389.424

51. SERRANO J. A.: BEAMAN, B. L: VILORIA, J E. ME JIA, M. A. \& ZAMORA, R. - Histological and ultrastruc tural studies of human actinomycetomas. In: SZABO, G BIRO. S. \& GOODFELLOW. M., ed - INTERNATIONAL SYMPOSIUM ON ACTINOMYCETFS BIOLOGY 6: DE bre`en, Hungary, 1985 Proceedings. Part. B. p. 647-662.
52. SERRANO J A \& MEJIA M A - El eumicetoma en el Estado Lara Las Micosis en Venezuela, $3: 2938,1987$

53. TIGHT, R. R. \& BARTLETT. M. S. - Actinomycetoma in the United States. Rev. infect. Dis., 3: 139250.1978

44. VANBREUSEGHEM, R. - The early diagnosis of Myce toma. Derm. int., 6:123 140.1967.

55. VARGAS MONTIEI., H. - Micetoma por Streptomyces somaliensis, primer caso en el Edo. Zulia (Venezuela). Derm. venez., 12: 161176,1973

56. VELUTINI, L. A - Sobre un caso de actinomicosis abdominal primitiva de la piel. In: JORNADAS VENEZO LANAS DE VENEROLOGIA DERMATOLOGIA Y LE PRA, 2.. Caracas, Venezuela, 1951. Proceedings. Caracas, Editorial Bellas Artes, 1951 , p. 519

57. VERGHERE. A. \& KLOKE.A. H. - Histologic diagnosis of species of fungus causing mycetomas. Indian I. med., Res. 54: 524-529, 1966.

58. VOLCAN, G - Cuatro casos de micetomas en veinte años de investigación. In: SIMPOSIO INTERNACIONAL DE MICETOMAs Barquisimeto, Venezuela, 1978. Procee. dings, Barquisimeto, Centro Tecnologia Educativa, 1978. v. 1. p. 303306

59. ZAMORA, R. \& BARROETA, S. - Pacientes con lesiones por Nocardia en la Ciudad de Barquisimeto. In: BROW NELL, G. ed. - INTERNATIONAL CONFERENCE ON THE BIOLOGY OF THE NOCARDIAE. Merida, Venezuela. 1974. Proceedings. p. 102.

Recebido para publicaçảo em 23:9:1987 